\author{
Miloš M. Damjanović \\ Faculty of Philosophy in Kosovska Mitrovica, University of Pristina \\ Kosovska Mitrovica \\ https://orcid.org/0000-0001-7017-790X \\ milos_damjanovic@yahoo.com
}

\title{
Relations among Jews and Gentiles in Kosovo and Metohija between the Two World Wars: From Autocentrism to Assimilation
}

\begin{abstract}
The period between the two world wars in Kosovo and Metohija (1918-1941) was a peak period of legal protection, economic development, national and political self-positioning, educational and cultural emancipation, and general progress of the local Jewish community. The local Sephardic community, dedicated to tradition, enriched by the presence of the most progressive Ashkenazi newcomers, and surrounded by the Islamic and Christian majority populations in the private and public arena, strived to access the broader, more general framework of modern societal trends. Encouraged by examples from the immediate surroundings, by the national Yugoslav framework and the more developed Jewish municipalities within the state, through daily and varied interaction with neighbors and institutional contact, a metamorphosis of the local Jewish community was enabled. Internal changes were partially conditioned by intensifying relations with the non-Jewish communities. They mostly accompanied these relations and were their inevitable outcome. Parallel to the development of increasingly diverse and more frequent contacts which were pursued in order to self-develop, to maintain and improve

\footnotetext{
This is an Open Access article distributed under the terms of the Creative Commons Attribution 3.0 PL License (creativecommons.org/licenses/by/3.0/pl/), which permits redistribution, commercial and non-commercial, provided that the article is properly cited. (c) The Author(s), 2020.

Publisher: Institute of Slavic Studies, Polish Academy of Sciences

Editor-in-chief: Jolanta Sujecka

Conception and academic editing of this issue: Aleksandra Twardowska, Katarzyna Taczyńska
} 
interethnic relations, at the social level there erupted elements of interethnic intolerance based on political, religious or economic grounds. Antisemitism strained and, alongside other factors (internal tightness, popular mentality, national tradition, religious differences), additionally complicated and halted closer cooperation. Besides these disagreements, integration into Yugoslav society was complete, especially among the young generation, but only in extraordinary conditions did it end in assimilation, which was exclusively enabled by the newly arrived Jews coming from other, more open and more cosmopolitan environments. This paper will show and elaborate on numerous examples of private and social collaboration between Kosovo-Metohijan Jews and other nations in the given chronological framework that were, above all, of wider importance for regional development and establishing civilizational heritage.

Keywords: Jews, Sephardim, Ashkenazim, Serbs, Albanians, Turks, Romani, Kosovo and Metohija, Kosovska Mitrovica, Priština.

\section{Introduction}

7 he life of Jews in Kosovo and Metohija in the early years of the 1 Yugoslav political system were marred by a painful break between the older generations, who belonged to the disappearing oriental world, and the younger generations locked in the warm embrace of the silent rise of a modern, European, and democratic form of pluralism. The public and private lives of adults and young people unfolded parallel to one another and at different paces. The Gordian knot that bound them to the past also shackled them to old habits and established conventions, giving rise to an endless nostalgia for times gone by. Despite this, an emerging new era promised wide-ranging freedoms, more opportunity, a more carefree existence and a view into a cloudless future that appealed to those at life's crossroads. These differences in perspective on life and circumstance conditioned the level and indeed the force with which younger Jews broke out into the outside world. Grounded in traditional norms inherited from the past, the older generations stayed devoted to a more limited scope of integration into the world of the Goyim. On the other hand, the younger Jewish citizenry emphatically engaged in interactions with the wider community.

According to even the most generous estimates, the number of Jews in Kosovo and Metohija between the two world wars never exceeded 1,000 individuals. According to a number of sources, during the year 1941 there were around 550 Jews in Kosovo, of whom 394 belonged to the Priština Jewish Community and 90 to the Jewish Community in Kosovska 
Mitrovica (Almuli, 2013, p. 18; Lazić, 2016, pp. 342, 436-438). However, their actual numbers are greater when taking into consideration those Jews who were not officially subsumed into organized Jewish communities. The majority of Kosovo's Jewry belonged to long-standing Sephardim circles situated largely in Priština and Kosovska Mitrovica. Apart from them, it is also necessary to take into account other categories of Jews, regardless of the length of their presence in Kosovo, such as the small numbers of Ashkenazi, White Russian and German immigrants. Belonging to one of these groups was often crucial in dictating the extent of their willingness or reservation in terms of the level of openness to their social surroundings.

\section{Sephardi, Ashkenazi and White Russian Jewish Immigrants}

The principal bearers of Jewish life in Kosovo were the Sephardim, who were wholly and officially grounded in their community. The Sephardim in Kosovo during this time were a prime example of what can be described as having double loyalties and dual identity. At one point, they were the strongest bulwark in maintaining and affirming the traditions of their ancestors while also being devoted and honorable members of Yugoslav society, regularly fulfilling their civic duties and enjoying the rights which that same society granted them. Despite a trend towards a more inclusive social life in a non-Jewish state and a closer orbit around all elements of civic life, they nonetheless developed an enormous degree of self-respect and a dedication to the interests of their kin. This was reflected in the ever-growing popularity of Zionist ideas as well as in organized and institutionalized activism through which they advocated for common interests (Damjanović, 2018b, pp. 281-316). Through versatile and persistent engagement within their community, they became unwavering guardians of their cultural heritage and identity. Even the far-reaching process of secularization, which young people in particular were caught up in, did not put much distance between them and their roots, except perhaps in a selected number of very rare instances.

The motive behind the arrival of the Ashkenazim in Kosovo was largely of a professional nature. The fact that these people came from abroad, had been raised and educated in developed European countries, and identified with the cosmopolitan spirit of larger urban areas, means that they continued to live completely independently of any kind of institutional connections with the Jewish community in Kosovo and Metohija. In addition, the nature of their work and indeed their lifestyle brought them into frequent and daily contact with their Christian and Islamic neighbors 
and fellow citizens: A doctor in Kosovska Mitrovica, Nehemiah Shonfein, lived exclusively with non-Jews both during his military service and as a civilian practitioner. He is an example of a Kosovo Jew who went the farthest in terms of the level of integration into society at large. Not only did he marry a woman of German origin from Switzerland, but he converted to Protestantism before the marriage and gave his Kosovo-born daughters Serbian names (Damjanović, 2018a, pp. 32-50). Since the family of Doctor Josef Teitelbaum was the only Jewish one in Prizren, they would have found it impossible to go about their lives without daily contact with the Serbian, Turkish and Albanian inhabitants of that city. We find proof of this in his son's testimony:

My nanny in early childhood was a Gypsy. We bought ice cream at a pastry shop owned by Pelivan, an ethnic Gorani, the baker was a Turk, we bought vegetables from an Albanian greengrocer, my mother bought filigree jewelry from an Albanian Catholic. All our neighbors and friends were Serbs or Montenegrins. My parents' social circle was a small group of Prizren's intelligentsia: lawyers, judges, gymnasium professors. Our best friends were the family of Dragutin Jakić, a local lawyer from a respectable old Prizren family. (Tajtelbaum, 2003, p. 164)

They were also among those who had no problem with accepting all the resources, advantages and benefits of public life with open arms. The father treated non-Jewish patients from both the military and the civilian population, the mother, Paula, was active in social life as a member of the local branch of the Circle of Serbian Sisters (Pravda, May 29, 1936, p. 4), and their son Raul attended state schools - so none of the family's members maintained consistent contact with their fellow Jews. Likewise, the family of a high-ranking military officer in Priština, Sigmund Komornik, whose wife Emilia and son Otto took part in all aspects of civic life, kept a distance from the Jewish community by not practicing Judaism and not attending their local synagogue (Author's interview with Otto's wife Ljiljana Komornik from Haifa, Israel, June 3, 2018).

Renowned Yugoslav athlete and political thinker Ivan-Vane Ivanović, who had Serbian, Jewish, Czech and Croatian roots and lived in Kosovo from time to time, came into regular contact with the local non-Jewish populations. He observed the peculiarities and civilizational advancements

\footnotetext{
1 "Moja dadilja u ranom detinjstvu bila je Ciganka. Sladoled smo kupovali u poslastičarnici Pelivana, Goranca, pekar je bio Turčin, povrće smo kupovali kod piljara Albanca, majka je kupovala filigranske nakite kod katolika, Albanca. Svi su naši susedi i prijatelji bili Srbi ili Crnogorci. Društvo mojih roditelja bio je onaj malobrojni krug prizrenske inteligencije: advokata, sudija, gimnazijskih profesora. Najbolje prijatelje imali smo u porodici Dragutina Jakića, mesnog advokata iz jedne ugledne stare prizrenske porodice".
} 
of indigenous groups through communication and familiarization with the localized nature and cultural-historical characteristics of various ethnicities, thereby constructing or reshaping notions and value judgements about them. Recalling his experience living in Kosovo decades later, and in completely different circumstances, Ivanović made the following observation about the Serbian and Albanian cultural milieu:

Over fifty years ago, I spent seven months living and working in Kosovo. I don't remember if, during that time, I noticed any Albanian historical monuments or other substantive traces of Albanian culture. There were, however, many Serbian ones, which is why, at least for me, a return of Serbian influence in Kosovo would not appear to be unnatural or unfeasible. (Ivanović, 1992, pp. 190-205) ${ }^{2}$

Members of the Ashkenazi community who only spent small amounts of time in Kosovo, and whose experiences were less diverse and wideranging than those of local Jews, had the least amount of contact with local residents as a result of different life circumstances. Interactions (with other groups) at times came down more to observation than live encounters, which can perhaps be explained by differences in mentality as well as feelings of hostility towards cultural values radically different from their own. Interwar Kosovo and its population left an impression of misery and backwardness on Yugoslav Jews who came from areas that were more economically advanced and culturally developed. Zagreb-born Mirko Mirković (Herman Friedman) (1913-2012), who lived in Kosovo during the April War of 1941, remarked: "I came to Kosovo with the Army. I was astonished by the sheer squalor of the people there" (Mirković, 1996, p. 167). ${ }^{3}$

Little is known about the life of Jewish White migrants to Kosovo during this time. A small number ended up in these none-too-hospitable or alluring areas. Judging by their surnames, there were possibly some immigrants of Jewish origin among the numerous Russian colonies in Kosovska Mitrovica and in neighboring Zvečan. They included Vyacheslav Frank, Vladimir Lichtmanovitch, Veniyamin (Benjamin) Rupcov and Luca Solomka, a builder in Zvečan (Frtunić, 2010, pp. 86-87). It is entirely conceivable that these were Russified Jews who had converted to Orthodox Christianity. We do not have concrete data on their lives or work, but confident assumptions can be made that they maintained close relations with their

\footnotetext{
2 “Пред више од педесет година ја сам живио и радио седам мјесеци на Косову. Не сјећам се да сам том приликом примјетио албанске културне споменике и друге замашније трагове албанске културе. Али српских је било много и зато, бар мени, не би повратак српског уплива на Косову изгледао ни неприродан ни неизведив."

3 "S vojskom sam krenuo na Kosovo. Zaprepastila me strašna bijeda tog stanovništva."
} 
fellow refugees and enjoyed friendly relations with Orthodox Serbs, with whom they shared a certain spiritual closeness and linguistic similarities. None of these factors necessarily acted as an impediment to professional and private interaction with members of other ethnic groups who inhabited the same space. They certainly belonged to the most peculiar group of Jews who deviated radically from their origins and whose arrival in Kosovo marked a drastic distancing from the Jewish substance. In accordance with their educated and erudite background, they took over clerical functions within local state institutions or, as experts, undertook leading roles in the public projects they were engaged in. Needless to say, within the scope of their professional lives and being free of interethnic animosities and prejudices, they moved exclusively in local circles and associated closely with local residents, with whom they succeeded in establishing all forms of relations. Examples of Jews who fit into this category included Leonid Gelfenbein, a state prosecutor with the Regional Court in Peć (Politika, March 4, 1937, p. 23); Leo Zaleman, an engineer from Uroševac (Radio Beograd - ilustrovani list, August 16, 1940, pp. 4, 15); Oskar Yakovlevich Weinstein, a former officer in the White Army, engineer and supplicant at the Peć Gymnasium (Arhiv Jugoslavije, Fond Ministarstva vera Kraljevine Jugoslavije, fond 69, f. 193, aj. 310, Ministarstvo vera Kraljevine SHS opšte odeljenje - Eparhijskoj konzistoriji Peć od 28. oktobra 1925; AJ, 69-193-310, Eparhijska konzistorija Peć od 9. novembra 1925; Olga Oskarovna Shestakova, n.d.), and Ivan Konigsberg (Politika, October 14, 1936, p. 8), a teacher at the Djakovica Civic School and the Peć Comprehensive School (Damjanović, 2016c, pp. 171-193).

\section{Experience of Antisemitism}

The relations between Jews and non-Jews in Kosovo and Metohija during the interwar period were marked by mutual respect and assistance, kindness, and cordiality. It is impossible to talk about the existence of even the slightest hint of the classic antisemitism that has been seen throughout the history of European countries. The majority ethnic groups did not nurture negative feelings or dark impulses towards Jews. Individual examples of hostility can be viewed as isolated incidents rather than a reflection of widespread indoctrination.

Although an archetypal phenomenon among European nations, antisemitism was alien to the Serbian people. Aside from short-lasting manifestations in the 19th century sparked largely by business-related conflicts, antisemitism never gained a foothold among the Serbs. Antisemitism made an appearance to a somewhat larger degree among 
certain Serbian intellectual thinkers, where it was accepted as a result of the influence of widespread anti-Jewish feelings originating from the German and Hungarian worlds (Damjanović, 2016a, pp. 505-518). However, aside from those fairly insignificant cases, relations between these two communities in Austria-Hungary were left undamaged, as can be seen from the example of financial assistance that banks in imperial Vienna provided, with substantial Jewish capital, to the Serbian community there for the purpose of building the Church of St. Sava (Spomenica, 1936, p. 26).

The German national minority in Yugoslavia spread antisemitic ideology through the press whose publication was supported by large amounts of cash originating from Berlin. The authorities in Belgrade were heavily criticized on its pages for having allowed German Jews to immigrate to the country (Vajagić, 2016, p. 131). The harmful activities of the German minority in Yugoslavia were partially offset by the progressive social activism of Serbian public figures who took a critical stance towards racist thought and its destructive political and social implications. The struggle for the neutralization of racist views proceeded on many fronts through propaganda offensives and speeches at mass gatherings. In Priština, as in certain other cities (Belgrade, Kumanovo, Skopje etc.), Dušan Nedeljković held a series of talks in 1936 and 1937 at the People's University on this topic, an opportunity he used for the publication of a book entitled Race and Racism, released in Skopje in 1937 (Koljanin, 2008, p. 348). This resulted in the suppression of the negative tendencies of certain antisemitic elements in society and extinguished the possibility that this sort of social weed should sprout up on Yugoslav, i.e. Kosovo soil.

The Yugoslav regime demonstrated a high level of understanding for and took steps to aid the many unlucky individuals who appeared at its borders. For Jewish refugees, its territory was the sole island of salvation on European soil. One Austrian-Jewish witness to these events commented many years later: "As an 84-year-old, I remember 1938, when the first Jews had to flee Austria, Belgrade was open. Two more nations were openhanded: Mexico and China" (Gerstl, 2008, p. 21).

Contemporaries of the Jewish community also recognized the Yugoslav authorities' demonstrations of hospitality and humanitarianism. The leaders of the Jewish Community in Skopje noted in their report that:

Our country was one of Europe's vents that served to take in a certain number of these unlucky people, whether it was to provide temporary shelter from the hell that they found themselves in, or to act as a transit stop on the road that would lead them to more distant lands and to Eretz. In light of this, our state administration and authorities must be given deep and honest recognition for all the noble ventures that 
they undertook, within the realm of possibility, for the members of our community in Yugoslavia. (Jevrejska veroispovedna opština u Skoplju, 1940, p. 11) ${ }^{4}$

According to an estimate made by Aleksandar Klein, general secretary for refugee assistance of the Zagreb Jewish Community, approximately 55,500 foreign Jews from countries under Nazi government or occupation passed through or emigrated to Yugoslavia between 1933 and 1941. Of those, 51,500 succeeded in leaving the country before the Nazi attack on Yugoslavia (Gruenfelder, 2018, p. 5).

The appearance of visible antisemitic acts and actions in Kosovo and Metohija was crucially and primarily spurred by German propaganda, and, to a much lesser extent, by isolated, unimportant domestic pro-German factions. The manifestation of anti-Jewish trends in Kosovo arrived with the ever-increasing German penetration of economic and political life in Yugoslavia. They materialized here and there, over short periods of time, in the waning days of the state body, or, in other words, during the death of Yugoslavia. Even then, these purveyors of antisemitic ideology found themselves without any stronghold among the people, they were rejected and discarded, and were thus forced to unceremoniously end their inhumane mission. An attempt to instill a national corpus can be seen in the newsletter of a political party with antisemitic leanings (Zbor sa Kosova, January 6, 1940).

The local right-wing monthly Rally from Kosovo, a newsletter for a fringe political movement called "Rally" (Zbor) that was headed by Smederevo lawyer and politician Dimitrije Ljotić (1891-1945), entered the market in Kosovska Mitrovica during the first nine months of 1940. It was soon shut down, most likely due to the fact that it sold poorly and was thus unprofitable and likely unpopular. The paper published articles with antisemitic content in line with its general political orientation and the movement's views and the interests for which it advocated. The newsletter's third issue included two articles ("Masons and Jews"; "Masons and Jews Are to Blame for Everything") whose content is revealed in the titles themselves; they are hostile towards not just Jews but also towards Masons, who are brought into a direct relationship without any basis (Vukadinović \& Bogavac, 2001, p. 236). Although this example of local

\footnotetext{
“Наша земља је била један од европских вентила, који су служили за пропуштање извисног броја ових несрећника, било ради привременог склањања од пакла који их је снашао, било пак као транзитни пут, који би их водио у друге далеке земље и у Ерец. У том погледу, нашој државној управи и властима мора се одати дубоко и искрено признање за све племените предусретљивости, које су у границама могућности указивале претставницима наше заједнице у Југославији."
} 
demonization of Jews by the media may have brought a temporary imbalance to the otherwise harmonic interethnic relations between Serbs and Jews in Kosovo and Metohija, it did not succeed in inflicting more serious damage to local Jewry or to create discord or disruption to existing good-neighborly relations - something that is reflected in the fact that the publication was so short-lived.

\section{Relations among Jewish and with non-Jews}

The Jews of Kosovo and Metohija also built their relations with nonJews on humanitarian grounds, showing solidarity with the suffering, impoverished and socially vulnerable citizens of Yugoslavia. In accordance with the material resources at their disposal, they provided assistance to institutions specialized in providing aid and services to people with special needs, such as the Institute for Blind and Deaf Invalids in Zemun that was founded in exile on December 13, 1917 in Bizerte (Tunisia) and transferred to the homeland upon its liberation (Ramadanović, 1937, pp. 34, 41-43). Touched by the suffering of those unlucky people, two Jewish pupils from the primary school in Priština, Zlata Koen and Mara J. Samuel, decided to enliven the Christmas holidays by sending them occasional gifts (Pravda, January 5, 1938, p. 17; Damjanović, 2016b, pp. 108-126).

The places of the most frequent encounters between Jews and other ethnic groups (Serbs, Romani, Turks and Albanians) included the çarşı and surrounding neighborhoods. Two-way communication was regularly established at markets in urban areas, in shops owned by Jews in cities and surrounding villages, as well as in other areas where buying and selling took place frequently. The working world also spilled over into the private sphere, were mostly Romani women were employed as nannies, cleaners and maids in Jewish households. Besides urban areas, Jews also engaged in business relations with the rural population, from whom they purchased various homemade products or sought a labor force to work land they possessed outside of the cities (Author's interview with Prištinaborn Moshe Solomon from Kidron, Israel, August 17, 2019). Another important channel of communication and shared living and working space between Jews and members of other national groups were state-run institutions. Across the country, in military buildings, schools, hospital rooms, doctor's offices, courtrooms, municipal corridors, Jews exercised their rights, fulfilled obligations, offered or used services to and from nonJewish colleagues, workers, teachers etc. with whom they got along and, circumstances permitting, even associated and enjoyed friendly relations outside of work. 
The religious domain was nevertheless closed to the outside world; it forbade rapprochement and was dominated by introversion. Besides an unfaltering dedication to the faith of their forebears, the Jews of Kosovo and Metohija avoided excessive mixing with outsiders during holiday periods. Despite precautions taken to protect the intimacy of the holidays, contact was nonetheless unavoidable. One Jewish woman from Belgrade who chanced upon the Levi home in Lipljan towards the end of 1941, described the atmosphere of celebration during Shabbat in their Kosovo Jewish household. She evokes a striking picture of the holidays in an average Jewish home between the two world wars. A traditional family, the Levis respected the faith of their ancestors and marked the most important day of the week in line with religious texts, family tradition and according to their financial means. They were joined, not infrequently, by their nonJewish neighbors as well as other friends or acquaintances who found themselves in their home. Neighborhood children would also gather to play at the Levi household during Shabbat. One evening, they were caught off guard by the unexpected arrival of an unannounced guest as they were sitting down to Shabbat dinner, a scene that soon became forever etched in the newcomer's memory:

It was Friday evening and an agrarian family was observing the Jewish day of rest. Candles were burning on the table, and despite their poverty, it was a very solemn affair. There were pastel on the table - meat pie, and beans. It was the beginning of Shabbat, the sixth day of the week [according to the global, Christian calendar], when no one works. Children were playing around them. (Almuli, 2010, p. 203)

French writer and essayist of Jewish origin Albert Memmi (1920) rightly remarked that not a single visible attempt at assimilation, especially mixed marriages as a prime example, could come to pass without bitter opposition from the Jewish community (Memmi, 1973, p. 91). The Jews in Kosovo and Metohija were no exception to this. All examples of converts leaving the community ended in their total condemnation and complete shunning, even by their closest family members. It is worth noting that the motives for conversion were not spiritual in nature but rather the result of marriage to a Christian. Perhaps the most drastic cases of rupture with Judaism and assimilation into the new surroundings were a small number of young women who, by their own decision and without the approval of their parents, married Serbian men. These assertions are further

\footnotetext{
“Био је петак увече и та земљорадничка породица је поштовала тај јеврејски благдан. Гореле су свеће за трпезом, било је врло свечано, иако врло сиромашно. На столу су били pastel - пита од меса, и пасуљ. Био је почетак Шабата, шестог дана у недељи, кад се не ради. Деца су се около играла."
} 
confirmed by the cases of Beja Mandilović, Bukica Bukić (Damjanović, 2013, pp. 60-74) and Meira Mandilović (Author's interview with Meira's relative Bojana Popović from Nova Gajdobra, Serbia, July 12, 2018).

Different forms of hybridization between Kosovo and Metohija's residents contributed to linguistic fluctuations in the shared living space. In the interwar period as well as the time leading up to it, all members of Kosovo's Sephardic population were familiar with and actively used both the languages spoken by their neighbors and other foreign tongues. Alongside the official Serbian language, the majority of them also spoke Albanian and Turkish. Albanophone and Turkophone Jewish citizenry generally belonged mostly to category of older Sephardic residents, while younger generations born, raised and educated in the Yugoslav state tended not to speak those languages. It is impossible to confirm with any great degree of certainty whether or not Jews from Kosovo and Metohija who settled in other parts of the country continued using minority languages. Jews from Pristina who settled in the Yugoslav capital and jumped into urban life were brought into daily professional contact with the numerous Albanian migrant workers, physical laborers and artisans from the southern regions of the country, and thus were afforded the opportunity to practice and refresh their knowledge of the Albanian and Turkish languages, preventing them from slipping from memory. Among the Jews of Belgrade who were born during the interwar period and survived the Holocaust, only one member of the community that was surveyed claimed to speak the Albanian language, which is perhaps indicative of his or his family's origins in Kosovo, and certainly reflects the ideological and cultural constructions of the chronotope from which the respondent comes (Vučina Simović, 2015, pp. 68-90; Vučina Simović \& Filipović, 2009, p. 145).

Although the Jews' native mother tongue, i.e. Judeo-Spanish, was used most frequently within family life and in interpersonal communication with other Jews, the multi-layered nature of the interactions that the Jewish population had with the wider population meant that sometimes outsiders learned how to speak it as well. It was mainly close, interpersonal relations that caused and contributed to the acquisition and usage of Ladino among non-Jews. New generations born and brought up in freedom, and who had contacts with the Jewish world from early childhood, easily and quickly became bilingual by familiarizing themselves with this fairly peculiar, unknown and unusual language and the world of its speakers. As the number of Jewish families in a given place fell, contacts with non-Jews became more frequent, and the intensity of those relations allowed for greater familiarization with the language and its usage. In places where 
there were larger numbers of Jews, who in turn were more inward-looking and reliant on other members of their community for social interactions, the opportunities for acquisition of the Ladino language by outsiders were obviously fewer. In Lipljan, the children of only two Jewish families that lived there filled much of their free time by socializing and building meaningful relationships with non-Jews. Even the sanctity and familial intimacy of the holidays could not separate them from their friends of other faiths. The woman from Belgrade who found herself on the Levis' doorstep for Shabbat and participated in an utterly remarkable scene that left her bewildered, gave this account of this unusual linguistic phenomenon:

The children were running around playing. It was then I realized that the girl was speaking to a little boy who was there in Spanish, or actually, Judeo-Spanish. I asked, 'Is this your child?'; 'No, that's a neighborhood kid.' Then how does he speak Judeo-Spanish? And they say: 'He plays with my children, he picked it up.' This episode speaks volumes about the life of Sephardic Jews in Kosovo. (Almuli, 2010$, p. 203 $)^{6}$

Though knowledge of Ladino among non-Jews was exceedingly rare, almost all of the Jews of Kosovo and Metohija were fluent in and actively used the language of the state. Serbian was not just the language of their public life; it also went deeper and touched upon the private sphere. Before the Holocaust brought Jewish life to a tragic end, the Jews were already reading daily and other newspapers in the Serbian language, and as confirmation of the extent to which Serbian had cemented itself among the Jews of Kosovo and Metohija, the last transcripts they left behind were written in Serbian (Lebl, 2002, pp. 33-36). Kosovo's Jews broke with their ancestors in the field of language, showing readiness to suppress their mother tongue into oblivion and replace it with a language that held greater practical significance in their daily lives. This attitude towards language was certainly justifiable, given that it facilitated and accelerated their general integration into Yugoslav society. Language appropriation sparked but did not end interaction with the outside world.

\section{Summary}

The Yugoslav experience among the Jews of Kosovo and Metohija during the interwar period was a golden era of their unobserved history

\footnotetext{
6 “Деца су се около играла. Тада сам приметила да мала говори са неким дечачићем, који се ту нашао, шпањолски, односно жудео еспањол. Питала сам: 'Да ли је и ово ваше дете?', 'Не, то је дете комшијско'. Како говори жудео еспањол? Каже: 'Игра се с мојом децом, научио је'. Та епизода говори о животу сефардских Јевреја на Косову.”
} 
in that region. Receiving the sudden and unexpected blessing of equality and modernization, they embraced and eagerly accepted it. The Jewish community in Kosovo and Metohija was small, hardly noticeable and insignificant. As a poor, primitive and underdeveloped community, the Jews could not assume high and significant positions in the new Yugoslav framework. Attachment to old customs, old understanding of the world and bygone times lasts the longest.

The older generations which remembered the Ottoman Empire barely got over being disconnected from yesterday. They kept on living their life according to the old patterns, steadfastly and consistently. In contrast to them, the new and young generations were penetrating into social life with enthusiasm, taking advantage of all available benefits.

The interwar period brought Jews from other areas and with different rituals - Ashkenazi and White Russian émigrés - as neighbors to the native Sephardim in Kosovo and Metohija. The Sephardim cherished a dual dedication: dedication to the country as its citizens, and dedication which was close and nationally defined through Zionist work. Rare Ashkenazi immigrants in Kosovo and Metohija were totally estranged from the life of the Jewish community and were concentrated on personal life, strongly incorporated into Yugoslav society, thus representing examples of the deepest assimilation. Side by side with them, although not numerous, were also White Russian émigrés of Jewish origin, who had no common ground with the Jewish community, organized Jewish life or Jewish identity, living a completely secular life.

All of them maintained most kindhearted, affectionate, friendly and intensive relations in personal, business and social life with members of various ethnic groups living in this territory: Serbs, Romani, Albanians and Turks. Serbian society was not acquainted with traditional antisemitism, so attempts at antisemitic activities at a local level were not accepted in public life and ended in inevitable and rapid failure. Interaction of the Jews in Kosovo and Metohija with the non-Jewish population went well in every field of family and social life - in neighborhood, trade and institutional work, humanitarian activities, in the field of language and religious holidays, where the Jews were the most reserved and inflexible. Total assimilation was possible only in those endemic and exceptional cases of mixed marriages when a Jew would abandon their community and join the new identity of their partner. 


\section{Archival Documentation}

Arhiv Jugoslavije, Fond Ministarstva vera Kraljevine Jugoslavije, fond 69, fascikla 193, arhivska jedinica 310 (AJ, 69-193-310).

\section{Author's Interviews}

Komornik Ljiljana, Haifa, Israel, June 3, 2018.

Popović Bojana, Nova Gajdobra, Serbia, July 12, 2018.

Solomon Moshe, Kidron, Israel, August 17, 2019.

\section{Press}

Politika, Beograd (1936, 1937)

Pravda, Beograd (1936, 1938)

Radio Beograd - ilustrovani list, Beograd (1940)

Zbor sa Kosova, Kosovska Mitrovica (1940)

\section{References}

Almuli, J. (2010). Stradanje i spasavanje srpskih Jevreja. Zavod za udžbenike.

Almuli, J. (2013). Ostali su živi. Zavod za udžbenike.

Damjanović, M. (2013). Rabini na Kosovu i Metohiji i duhovni život Židova Kosova i Metohije. ESSEHIST - časopis studenata povijesti i drugih društvenohumanističkih znanosti, 5, 60-74.

Damjanović, M. M. (2016a). Grigorije Božović i jevrejsko pitanje. In D. Andrejević \& A. Kostić Tmušić (Eds.), Poetika Grigorija Božovića (tematski zbornik vodećeg nacionalnog značaja) (pp. 505-518). Filozofski fakultet Univerziteta u Prištini; Filozofski fakultet Univerziteta u Nišu; Kulturni centar "Stari Kolašin”.

Damjanović, M. M. (2016b). Language changes in the Jewish Community in Kosovo and Metohija after the Balkan Wars (1912-1913) and the First World War (1914-1918). In C. Declercq \& J. Walker (Eds.), Languages and the First World War: Representation and memory (pp. 108-126). Palgrave MacMillan. https:// doi.org/10.1057/9781137550361_8

Damjanović, M. M. (2016c). Netipični Rusi: Kalmici, Jevreji i Cigani među beloemigrantima u Jugoslaviji 1918-1941. Baština, 2016(41), 171-193.

Damjanović, M. M. (2018a). Dr Nehemije Šenfajn - Biografija žrtve Holokausta. Topola - časopis JU Spomen-područja Donja Gradina, 4, 32-50.

Damjanović, M. M. (2018b). Počeci, razvoj i aktivnosti cionističkog pokreta na Kosovu u Metohiji 1918-1941. Srpske studije, 9, 281-316.

Frtunić, D. (2010). Šeher-Mitrovica pod Zvečanom. Književno društvo Kosova i Metohije.

Gerstl, A. (2008). [Conference speech]. In Z. Antonić (Ed.), Jasenovac: Zbornik izlaganja Četvrte međunarodne konferencije o Jasenovcu (pp. 21-22). Javna ustanova Spomen-područja Donja Gradina; Udruženje Jasenovac. 
Gruenfelder, A. M. (2018). Sustigla ih Šoa: Strani židovski izbjeglice u Jugoslaviji (1933.1945.). Srednja Europa.

Ivanović, V. (1992). Uloga nesrpskih naroda Jugoslavije u problemu Kosova. In D. Subotić (Ed.), Neugašeno srpstvo: Srpska politička emigracija o srpskom nacionalnom pitanju (1945-1990): Zbornik (pp. 190-205). Društvo Srpska krajina.

Jevrejska veroispovedna opština u Skoplju. (1940). Izveštaj o radu Uprave i Odbora Jevrejske veroispovedne opštine u Skoplju u izbornom periodu 1936/1939 god. Štamparija Vasilija Dimitrijevića.

Koljanin, M. (2008). Jevreji i antisemitizam u Kraljevini Jugoslaviji 1918-1941. Institut za savremenu istoriju.

Lazić, V. Ž. (2016). Uvod u smrt: Numerus clausus 1940. godine i ograničavanja prava Jevreja u Kraljevini Jugoslaviji. Akademija za nacionalnu bezbednost; Javno preduzeće "Službeni glasnik".

Lebl, Ž. (2002). Do "konačnog rešenja”: Jevreji u Srbiji. Čigoja štampa.

Memmi, A. (1973). The liberation of the Jew. The Viking Press.

Mirković, M. (1996). Svijet koji je nestao. In J. Domaš Nalbantić (Ed.), Obitelj (pp. 163-168). Kulturno društvo "Miroslav Šalom Freiberger”; Novi liber.

Olga Oskarovna Shestakova. (n.d.). http://olga.weiv.org/

Ramadanović, L. V. (1937). Zavod za slepe i gluve ratne invalide u Bizerti. In A. Skala (Ed.), Spomenica Domova slepih viteškog kralja Aleksandra I Ujedinitelja - Zemun 1917-1937 (pp. 33-46). Dom slepih.

Spomenica o sedamdesetpetogodišnjici Srpske pravoslavne crkveno-školske opštine u Beču 1860-1935. (1936). Izdanje Crkvenog odbora srpske opštine Beč.

Tajtelbaum, R. (2003). Prizrenska elegija. In A. Gaon (Ed.), Mi smo preživeli...: 2. Jevreji o Holokaustu (pp. 160-185). Jevrejski istorijski muzej Saveza jevrejskih opština Srbije i Crne Gore.

Vajagić, M. P. (2016). Banovi Dunavske banovine. Akademska knjiga; Društvo nastavnika istorije.

Vučina Simović, I. (2015). Odabir jezika među beogradskim Sefardima u moderno doba. Balkanija - časopis za balkanske studije, 6, 68-90.

Vučina Simović, I., \& Filipović, J. (2009). Etnički identitet i zamena jezika u sefardskoj zajednici u Beogradu. Zavod za udžbenike.

Vukadinović, Č. Z., \& Bogavac, J. M. (2001). Srpska prosveta i kultura u Kosovskoj Mitrovici 1836-1941. Institut za srpsku kulturu; Učiteljski fakultet. 
Односи Јевреја и нејеврејског становништва на Косову и Метохији између два светска рата - од аутоцентричности до асимилације

Период између два светска рата на Косову и Метохији 1918-1941 је важна епоха правне заштите, економског развоја, националнополитичког самоодређења, просветно-културне еманципације и општег прогреса овдашње јеврејске заједнице. Традицији одана локална сефардска заједница, обогађенапримесама прогресивнијихашкенаских дошљака и окружена већинским исламским и хришћанским народима у приватном и јавном домену тежила је ступању на шири, општи колосек савремених друштвених кретања. Подстакнута примерима из ближе средине, националних југословенских оквира и развијенијих јеврејских општина у држави, кроз свакодневна разноврсна прожимања са суседима и институционално саобраћање, долазило је до метаморфозе овдашње јеврејске заједнице. Унутрашње промене делимично су биле условљене интензивирањем односа са нејеврејским светом, оне су по правилу пратиле те релације и биле њихов неизбежан резултат. Паралелно са одвијањем све разноврснијих и учесталијих контаката којима су се изграђивали, одржавали и побољшавали међуетнички односи, избијали су на друштвену површину и елементи међуетничке нетрпељивости базирани на политичкој, верској или привредној сфери. Антисемитизам је оптерећивао и уз неке друге чиниоце (унутрашња затвореност, менталитет становника, народна традиција, разлике у вероисповести) додатно отежавао и заустављао још тешњу сарадњу. И поред оваквих опрека, интеграција у југословенско друштво је, нарочито међу младом генерацијом, била комплетна, али се само изузетно окончавала асимилацијом, и то искључиво код новопридошлих Јевреја, који су потицали из других, отворенијих и космополитскијих средина. У раду ће се приказати и објаснити бројни примери приватних и друштвених кооперација између косовскометохијских Јевреја и осталих народа у датим хронолошким оквирима који су доминантно били од ширег значаја за регионални развој и успостављање цивилизацијских тековина.

Кључне речи: Јевреји, Сефарди, Ашкенази, Срби, Албанци, Турци, Роми, Косово и Метохија, Косовска Митровица, Приштина. 
Relacje Żydów ze społecznością nieżydowską w Kosowie i Metochii między dwiema wojnami światowymi - od autocentryzmu do asymilacji

Okres między dwiema wojnami światowymi w Kosowie i Metochii (1918-1941) to ważna epoka ochrony prawnej, rozwoju gospodarczego, samostanowienia narodowo-politycznego, emancypacji edukacyjnokulturowej i ogólnego rozwoju tamtejszej społeczności żydowskiej. Wierna tradycji lokalna społeczność sefardyjska, wzbogacona o wpływy bardziej postępowych przybyszów aszkenazyjskich i otoczona w większości przez ludność islamską i chrześcijańską, w sferze prywatnej i publicznej aspirowała do wejścia na szerszą, ogólną ścieżkę współczesnych ruchów społecznych. Zachęcona przykładami $\mathrm{z}$ najbliższego otoczenia - ze strony narodów jugosławiańskich i bardziej rozwiniętych społeczności żydowskich w kraju, poprzez codzienne różnorodne obcowanie $\mathrm{z}$ sąsiadami i poprzez kontakty instytucjonalne, lokalna społeczność żydowska uległa metamorfozie. Zmiany wewnętrzne były częściowo uwarunkowane intensyfikacją stosunków ze światem nieżydowskim, z reguły podążały za tymi stosunkami i były ich nieuniknionym skutkiem. Równolegle z rozwojem coraz bardziej zróżnicowanych i częstszych kontaktów budujących, utrzymujących i poprawiających relacje międzyetniczne, na płaszczyźnie społecznej pojawiały się elementy nietolerancji międzyetnicznej, wynikającej z kontekstu politycznego, religijnego i ekonomicznego. Antysemityzm, oprócz kilku innych czynników (zamknięcie wewnętrzne, mentalność mieszkańców, tradycja ludowa, różnice wyznaniowe), dodatkowo obciążał i wstrzymywał jeszcze ściślejszą współpracę. Mimo tych sprzeczności integracja ze społeczeństwem jugosłowiańskim, zwłaszcza wśród młodego pokolenia, była pełna, ale tylko w wyjątkowych przypadkach kończyła się asymilacją, wyłącznie wśród nowo przybyłych Żydów, pochodzących $\mathrm{z}$ innych, bardziej otwartych i kosmopolitycznych środowisk. W artykule zostaną przedstawione i omówione liczne przykłady prywatnej i społecznej współpracy Żydów z Kosowa i Metochii z innymi narodami w podanych ramach chronologicznych, które miały przede wszystkim szersze znaczenie dla rozwoju regionalnego i postępu cywilizacyjnego.

Słowa kluczowe: Żydzi, Sefardyjczycy, Serbowie, Albańczycy, Turcy, Romowie, Kosowo i Metochia, Kosowska Mitrowica, Prisztina.

Przekład z języka serbskiego Katarzyna Taczyńska 


\section{Note}

Miloš M. Damjanović, University of Pristina - Faculty of Philosophy in Kosovska Mitrovica, Kosovska Mitrovica.

milos_damjanovic@yahoo.com

The preparation of this article was self-funded by the author.

No competing interests have been declared.

\section{Publication History}

Received: 2020-01-17; Accepted: 2020-12-04; Published: 2020-12-31 